DOI: https://doi.org/10.47405/mjssh.v6i8.955

\begin{tabular}{|c|c|}
\hline 4 & Malaysian Journal of Social Sciences and Humanities (MJSSH) \\
\hline $\begin{array}{l}\text { Malaysian Juoural of } \\
\text { Social ccciecces and }\end{array}$ & Volume 6, Issue 8, August 2021 \\
\hline (MJ-sSH) & e-ISSN : 2504-8562 \\
\hline & $\begin{array}{l}\text { Journal home page: } \\
\text { www.msocialsciences.com }\end{array}$ \\
\hline
\end{tabular}

\title{
Teori Kitaran Dasar: Penilaian Terhadap Implementasi Dasar Pandang ke Timur di Malaysia
}

\author{
Hanim Ismail1', Kartini Aboo Talib@Khalid'1, Nurul Asmaa Ramli1 \\ ${ }^{1}$ Institut Kajian Etnik, Univeristi Kebangsaan Malaysia (UKM) \\ Correspondence: Hanim Ismail (hanimismail_ummuhadi@yahoo.com)
}

\begin{abstract}
Abstrak
Apabila kerajaan memutuskan untuk melaksanakan sesuatu dasar, maka dasar tersebut akan dilaksanakan dan agensi pelaksana adalah pihak yang bertanggungjawab untuk memastikan sesuatu dasar yang diputuskan oleh kerajaan itu dapat dilaksanakan sepenuhnya. Setiap dasar yang diperkenalkan mesti mempunyai matlamat dan objektif tertentu bagi menyelesaikan sesuatu masalah atau isu yang timbul di dalam sesebuah negara. Dasar yang diperkenalkan oleh kerajaan adalah berbentuk undang-undang, peraturan, peruntukan mahupun serangkaian program. Bagi melihat keberjayaan sesuatu dasar yang telah dilaksanakan mencapai objektif atau matlamat dasar, suatu penilaian dasar perlu dilaksanakan. Penilaian dasar boleh dilaksanakan dengan menggunakan Teori Kitaran Dasar di dalam ilmu Analisis Dasar Awam. Penilaian dasar yang dibuat boleh mengenal pasti tahap kejayaan dasar, halangan dan kekangan perlaksanaan dasar, kelangsungan dasar serta solusi penambahbaikan dasar. Penilaian terhadap dasar yang telah dilaksanakan berupaya mengukur pencapaian dasar dengan melihat sejauh mana dasar yang dilaksanakan berupaya menyelesaikan masalah atau sesuatu isu serta kecekapan dan keberkesanan kos yang berbentuk kewangan mahupun bukan kewangan yang wujud di sepanjang perlaksanaan dasar. Perlaksanaan Dasar Pandang Ke Timur (DPT) yang diperkenalkan oleh Tun Mahathir Mohamad pada tahun 1982 telah hampir mencapai tempoh 40 tahun perlaksanaannya boleh dinilai berdasarkan pendekatan penilaian dasar yang diketengahkan di dalam Teori Kitaran Dasar. Penilaian terhadap DPT berupaya mengenal pasti sejauhmana dasar tersebut telah berupaya untuk mencapai objektif utamanya iaitu mengubah budaya dan etika kerja masyarakat Malaysia menjadi seperti rakyat Jepun.
\end{abstract}

Kata kunci: Teori Kitaran Dasar, Perlaksanaan Dasar, Penilaian Dasar, Dasar Pandang Ke Timur

\section{Policy Cycle Theory: An Evaluation of The Implementation of The Look East Policy in Malaysia}

\begin{abstract}
When a government decides to establish a new policy, the particular policy will be implemented, and the executor agency will be responsible to ensure that a particular policy which has been decided by the government can be fully executed. Every introduced policy must serve a particular purpose or objective to solve problems or issues that are happening in a country. Policies which are introduced by the government can be in the form of laws, rules, allocations and also a series of programmes. To see the effectiveness of an implemented policy in achieving the objective or motive of the policy, a policy evaluation has to be conducted. Evaluation of a policy can be carried out with the Policy Cycle Theory in the Public Policy Analysis. The evaluation of policy which is carried out can identify the success
\end{abstract}


level of the policy, the obstacles and constraints in implementing the policy, the sustainability and the improvising steps for the policy. Evaluation of the policies that have been implemented is capable of measuring the success rate of the policy by looking at the extent to which the implemented policy is able to solve a problem or an issue as well as the efficiency and effectiveness of costs in monetary and non-monetary forms that exist throughout the implementation of the policy. The implementation of the Look East Policy which is known as Dasar Pandang Timur (DPT) was presented by Tun Mahathir Muhamad in 1982 and has reached 40 years of implementation can be evaluated based on the policy evaluation approach which is highlighted in the Policy Cycle Theory. The assessment towards DPT was capable of identifying to what extent to which the policy has been able to achieve its main objective of changing the culture and work ethics of Malaysian society to be like the Japanese.

Keywords: Policy Cycle Theory, Policy Implementation, Policy Evaluation, Look East Policy

\section{Pengenalan}

Dasar Pandang ke Timur (DPT) dilaksanakan secara rasminya pada tahun 1982 apabila Tun Mahathir Mohamad telah mengumumkan perlaksanaan dasar ini pada 8 Febuari 1982 semasa persidangan '5th Join Annual Conference of MAJECA/JAMECA' di Hotel Hilton, Kuala Lumpur (Laman web rasmi Pejabat Perdana Menteri Malaysia). DPT mengambil contoh dan merujuk kepada negara Timur yang maju dan berkembang pesat dalam pembangunan dan kemajuan ekonomi. Matlamat perlaksanaan DPT adalah untuk mencontohi dan mengadaptasikan budaya dan etika kerja negara-negara Timur seperti Jepun, Korea, Taiwan, Hong Kong dan China ke dalam masyarakat Malaysia. DPT mempunyai dua objektif utama iaitu DPT adalah usaha meningkatkan kemahiran, kecekapan, pengetahuan serta menerapkan nilai-nilai yang positif dari Jepun dan Korea dalam etika kerja. Kedua, bertujuan untuk meningkatkan daya pengeluaran dan mutu kerja.

Budaya dan etika kerja masyarakat Jepun ini dilihat oleh Tun Mahathir Mohamad sebagai suatu budaya yang wajar dicontohi oleh rakyat Malaysia untuk diadaptasikan dalam diri setiap individu di Malaysia. Mahathir Mohamad telah menyatakan sebab beliau memilih untuk memperkenalkan dan melaksanakan DPT ketika beliau ditemu bual oleh penulis seperti di bawah:

"Saya biasa hidup pada zaman British dan saya berasa terhina. Sebab dia penjajah dan kita kena panggil Tuan pada mereka. Dan mereka pandang rendah pada kita. Jadi perasaan itu memang adalah. Saya pula baca banyak. Saya study banyak juga tentang cara hidup orang British. Mereka sudah jadi malas, tak mahu kerja kuat. Mereka tubuh union, dan union ini tuntut yang bukan-bukan. Become not produktif produk mereka. Tidak boleh lawan produk dari Jepun. Itu mempengaruhi saya untuk tidak menerap nilai Barat. Sebaliknya di Timur, saya pergi ke Jepun pada tahun 1961 jauh sebelum saya jadi PM. Masa itu Jepun sedang membina semula negara dia sebab rosak hancur habis kerana perang. Dan saya lihat mereka bekerja rajin, bekerja bersungguh-sungguh, buat kerja untuk bangunkan semula Jepun. Lepas itu saya baca buku Akio Morita founder of SONY dan dia cerita bagaimana pekerja-pekerja sanggup bekerja dan dibayar hanya a ball of rice dan makan soya sauce sahaja. Mereka rajin. Mereka bertanggungjawab. Mereka mudah selesaikan masalah. Umpamanya, saya tengok satu kereta Jepun bertembung dengan kereta lain. Naik kereta berlanggar, mereka berbincang. Angguk-angguk dan mereka pergi, selesai masalah. Lain daripada kita nak berkelahi. Saya dapati jika nilai ini diserap oleh orang Melayu, saya yakin mereka akan berjaya. Sebab itu saya ambil keputusan untuk pandang ke Timur, sebab masa itu orang pandang Barat. Barat dianggap sebagai tempat orang yang berjaya. Memang dulu mereka berjaya tapi orang Jepun datang dari belakang dapat mengejar dan mendahului orang Barat. Sebab itu kita patut tiru orang Jepun, bukan saja Jepun tapi negara di Timur ini”. 
Tun Mahathir Mohamad merasakan Malaysia perlu mengubah pandangan dari Barat ke Timur bagi mencapai kemajuan kerana beliau berpandangan, pada ketika itu Barat bukan lagi menjadi sebuah negara yang wajar diteladani kerana Barat telah berubah menjadi kurang produktif berbanding negara Timur yang kian pesat membangun terutamanya dalam sektor ekonomi. Oleh yang demikian, beliau telah memperkenalkan Dasar Pandang ke Timur dengan memberi tumpuan kepada dua bidang utama iaitu perindustrian dan pendidikan dengan hasrat, Malaysia mampu menjadi maju seperti Jepun sementelah rakyatnya mengamalkan budaya kerja seperti orang Jepun. DPT kini telah mencapai usia hampir 40 tahun perlaksanaannya tanpa pernah diisytiharkan dasar ini ditamatkan malah dasar ini diperkukuh dan diperkasa dengan memperkenalkan gelombang kedua DPT yang lebih dikenali sebagai DPT 2.0 pada tahun 2012. Kertas kerja ini meneliti dan menilai DPT selepas tiga puluh tahun bersama perlaksanaan DPT 2.0. Oleh kerana DPT merupakan salah satu daripada dasar awam, maka penilaian ke atas DPT dilaksanakan berdasarkan kepada ilmu analisis dasar awam.

\section{Analisis Dasar Awam}

Dasar awam merupakan suatu program atau undang-undang yang diperkenalkan oleh pihak kerajaan di dalam sesebuah negara bagi mengatasi masalah atau isu yang berlaku di dalam sesebuah negara. Sabitha (2001) mendefinisikan dasar awam sebagai suatu keputusan dalam bentuk pilihan dan penyelesaian kepada masalah, suatu matlamat atau objektif, serangkaian program, suatu peruntukan, undang-undang, ataupun peraturan. Dasar awam sebagai apa sahaja keputusan dan tindakan kerajaan untuk melakukan atau tidak melakukan sesuatu. Secara umumnya, setiap keputusan yang diambil oleh kerajaan pasti mempunyai objektif, matlamat dan tujuan serta tindakan kerajaan ini boleh dijadikan panduan umum dalam mengatasi masalah sesebuah negara. Secara tidak langsung, dasar awam itu juga merupakan sesuatu tindakan yang mempunyai kaitan dengan kepentingan rakyat dan boleh mempengaruhi rakyat. Shafritz et al. (2013) turut mendefinisikan dasar awam sebagai keputusan kerajaan sama ada untuk melakukan atau tidak melakukan sesuatu. Ia juga respon kerajaan terhadap isu politik. Program awam merupakan aktiviti yang dirancang oleh kerajaan untuk melaksanakan dasar awam.

Dasar awam adalah suatu proses kompleks yang melibatkan proses pembuatan keputusan oleh seseorang individu mahupun organisasi. Terdapat pelbagai pendekatan yang boleh diambil dalam sesuatu proses untuk membuat keputusan dalam proses dasar awam yang melibatkan keputusan kerajaan. Dasar awam juga merupakan salah satu elemen penting dalam sistem politik yang berhubung dengan rakyat atau orang awam. Sesetengah penganalisis memfokuskan kepada organisasi kerajaan untuk memahami pembuatan atau penghasilan dasar awam (public policy-making). Analisis dasar awam merupakan proses untuk menilai konteks dasar dari segi objektif, perlaksanaan, impak, dan kebaikan/keburukan yang terhasil darinya.

Dunn (2003) menjelaskan matlamat utama analisis dasar adalah untuk menambahbaikkan pembuatan sesuatu dasar. Penilaian dasar awam dilakukan selama beberapa tempoh masa selepas sesuatu dasar dilaksanakan. Ia merupakan suatu proses untuk mengkaji sesuatu dasar yang telah dilaksanakan itu sama ada telah berjaya mencapai matlamat ataupun belum. Jika terdapat perkara yang belum dicapai atau tersasar proses intervensi adalah pendekatan yang kerap digunakan bagi memastikan objektif asal dasar dapat dicapai. Analisis dasar adalah melibatkan proses untuk memastikan sesuatu tindakan yang diambil di dalam proses mencari penyelesaian terhadap sesuatu masalah yang dihadapi di dalam sesebuah negara memenuhi keperluan rakyat dan isu yang timbul.

Sabatier (1999) pula telah menyenaraikan proses dasar adalah seperti inisiatif awal, jangkaan, memilih, melaksana, menilai dan menamatkan atau menghapuskan. Walau bagaimanapun, konsep yang disenaraikan ini bukanlah secara tepat diterima oleh semua ahli akademik, tetapi ia dilihat sebagai suatu kombinasi yang baik kepada konsep dasar awam dan ia adalah penting dalam sesuatu proses dasar. Proses ini saling berkaitan di antara satu sama lain dalam sesuatu proses dasar. Proses dasar yang melibatkan proses menganalisis sesuatu dasar pasti melalui beberapa proses seperti yang telah disenaraikan bagi memastikan sesuatu dasar itu dapat dilaksanakan dengan baik. Berdasarkan pandangan Angela Browne dan Wildavsky dalam Sabatier (1999), mereka menerangkan bahawa proses 
di antara perlaksanaan (implementation) dan penilaian (evaluation), adalah penting untuk dikekalkan dalam amalannya kerana ia melindungi proses analisis daripada terjejas di antara satu sama lain.

Weimer dan Vining (1998) mentakrifkan proses analisis dasar bertujuan menjelaskan penilaian sama ada sesebuah dasar itu baik atau tidak untuk individu, masyarakat mahupun negara. Bagaimanapun, bukan semua pengukuran keberjayaan sesuatu dasar itu berpaut kepada matlamat dasar semata-mata tetapi proses memahami peringkat pencapaian itu yang diutamakan bagi penambahbaikan yang berterusan. Hasil sesebuah dasar yang wujud itu perlu berkait dengan usaha kerajaan menyumbang kepada masyarakat. Oleh itu, analisis dasar perlu berorientasikan pelanggan yang seiring dengan matlamat dasar yang relevan dengan kepentingan awam yang membawa kepada kesejahteraan masyarakat. Oleh yang demikian, ia perlu lebih spesifik untuk mengenal pasti ia sebagai analisis dasar. Analisis dasar mengambil kira sebab dan akibat serta implikasi sosial yang komprehensif bagi mencapai kelestarian pembangunan manusia dan fizikal.

\section{Teori Kitaran Dasar}

Proses pembuatan dasar perlu melalui beberapa peringkat. Peringkat yang dilalui ini dikenali sebagai proses kitaran dasar atau policy cycle. Pada dasarnya, ia merupakan suatu proses yang dikenali sebagai proses analisis dasar awam tetapi terdapat perbezaan di antara penulis yang membincangkan mengenai analisis dasar awam ini. Perbezaan yang timbul di antara penulis ini biasanya ditunjukkan dengan model yang diperkenalkan mereka. Walau bagaimanapun ia merupakan proses yang hampir sama dan setiap penulis mempunyai peringkat proses dasar yang hampir sama di antara satu sama lain. Analisis terhadap proses pembuatan dasar memfokuskan kepada proses pembuatan keputusan oleh kerajaan serta persekitaran luar yang mempengaruhi tingkah laku kerajaan dalam membuat keputusan.

Howlett dan Ramesh (1995) menyatakan, policy cycle atau Teori Kitaran Dasar terbahagi kepada lima peringkat iaitu pemilihan agenda (Agenda setting), memformulasikan dasar (Policy Formulation), pembuatan keputusan (Decision Making), perlaksanaan dasar (Policy Implementation) dan penilaian dasar (Policy Evaluation). Pemilihan agenda (Agenda setting) adalah merujuk kepada proses memilih daripada isu-isu yang disenaraikan dan pihak kerajaan perlu memberi perhatian kepada isu yang utama. Memformulasi dasar (Policy Formulation) pula merujuk kepada proses mengenal pasti strategi, formula dan mekanisme yang sesuai bagi memilih pemilihan dasar yang dibuat oleh kerajaan. Pembuatan keputusan (decision making) merujuk kepada kerajaan mengambil keputusan sama ada untuk membuat tindakan atau tidak mengambil tindakan.

\section{Rajah 1: Kerangka Teori Kitaran Dasar}

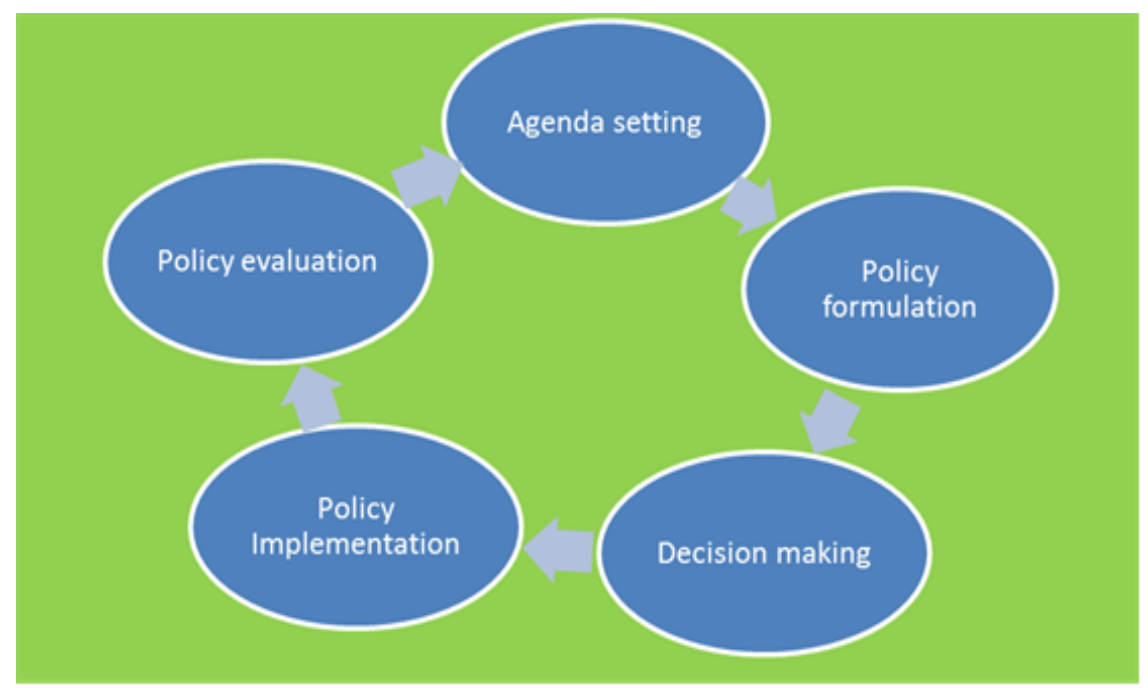

Sumber: Howlett \& Ramesh (1995) 
Manakala, policy implementation adalah proses di mana kerajaan melaksanakan dasar kepada rakyat dan policy evaluation adalah proses yang melibatkan penilaian terhadap dasar yang telah dilaksanakan. Dalam peringkat ini, impak sosial dan modal insan sama ada menyumbang kepada kebaikan atau keburukan akan dinilai. Kajian yang dibuat akan menentukan kejayaan atau kegagalan dalam perlaksanaan sesuatu dasar. Model Teori Kitaran Dasar yang diperkenalkan oleh Howlett dan Ramesh (1995) telah dipersembahkan berdasarkan Rajah 1.

\section{Penilaian Dasar (Policy Evaluation)}

Weiss (1997) mendefinisikan penilaian sebagai suatu proses yang sistematik terhadap operasi dan hasil daripada perlaksanaan dasar atau program, dibandingkan dengan jelas dan standard mutlak, bermakna dasar yang dilaksanakan telah menyumbang kepada penambahbaikan program atau dasar. Berdasarkan definisi, terdapat lima kata kunci yang utama dalam menerangkan maksud penilaian dasar. Kata kunci yang pertama adalah penilaian yang sistematik. Ini bermaksud penilaian yang mempunyai beberapa indikator yang tertentu tidak kira sama ada penilaian tersebut berbentuk kuantitatif mahupun kualitatif. Penilaian yang sistematik ini mempunyai formula yang tertentu yang dipatuhi secara formal mengikut standard penilaian yang telah ditetapkan. Seterusnya, penilaian haruslah menumpukan kepada operasi dan hasil program yang telah dijalankan. Ia melibatkan bagaimana program itu telah dijalankan. Terdapat sesetengah penilaian pula memberi tumpuan kepada hasil program atau dasar dan juga kesan kepada perlaksanaan dasar atau program tersebut. Penilai akan menilai sejauh mana sesuatu program yang telah dilaksanakan itu memberi faedah dan kelebihan kepada kumpulan sasaran.

Elemen yang seterusnya adalah berkaitan dengan perbandingan yang seragam. Proses ini mengumpul hasil perlaksanaan dasar dan akan dibandingkan dengan jangkaan hasil program yang telah dilaksanakan. Penilaian ini akan memfokuskan kepada proses program ataupun hasilnya, dan ia akan menentukan sama ada ia memenuhi kriteria yang dijangka mahupun tidak. Hasil dasar akan dinilai sama ada ia telah memenuhi matlamat dasar yang telah digariskan sebelum ia dilaksanakan ataupun tidak. Walau bagaimanapun, matlamat rasmi bagi sesuatu dasar bukan merupakan sumber utama untuk menentukan kriteria penilaian yang telah digunakan. Standard lain yang digunakan untuk menilai boleh hadir apabila jangkaan daripada aktor lain bergantung kepada program atau dasar. Objektif penganjur program, pengurus program, pengamal dan peserta program boleh menjadi kriteria dalam penilaian. Dalam sesetengah kes, penilaian terhadap dasar atau program menawarkan penilaian yang sistematik.

Elemen yang terakhir bagi definisi penilaian adalah tujuan bagi sesuatu program yang telah dijalankan. Ini melibatkan sumbangan kepada penambahbaikan program mahupun dasar. Penilaian ini membantu merangka program telah dijalankan dengan lebih baik dan mengalokasi sumber program dengan baik. Penilai menjangkakan orang yang berautoriti akan menggunakan keputusan penilaian untuk mengambil tindakan yang bijak. Mereka akan melihat kepuasan sebagai peluang untuk menyumbang kepada kebaikan sosial. Menjalankan penilaian mengikut proses tertentu memerlukan masa yang panjang dan juga menelan kos yang besar. Howlett dan Ramesh (1995) telah menggariskan tiga jenis penilaian dasar iaitu administrative evaluation, judicial evaluation dan political evaluation.

\section{Elemen Teori Kitaran Dasar dalam Aspek Penilaian Dasar (DPT)}

Berdasarkan Teori Kitaran Dasar, setiap dasar yang dilaksanakan oleh kerajaan perlu melalui lima peringkat kitaran dasar iaitu pemilihan agenda, memformulasikan dasar, pembuatan keputusan, perlaksanaan dasar dan penilaian dasar. Namun, ia berbeza dengan DPT apabila DPT bersifat top-down iaitu merupakan arahan langsung daripada Perdana Menteri kepada perbendaharaan dan kementeriankementerian untuk menyokong, mendukung dan melaksanakan DPT. DPT tidak dibincangkan di dalam Parlimen (Mohd Ikbal, 2015) dan mengetepikan proses Teori Kitaran Dasar yang idealnya meletakkan penghasilan dasar itu berlaku secara berperingkat dan mematuhi tertib kitaran dasar. DPT sama sekali tidak melalui peringkat dalam teori kitaran dasar ini. Pengenalan dan perlaksanaan dasar ini yang bermula dengan Perdana Menteri, Tun Mahathir Mohamad pada ketika itu yang merasakan satu usaha atau dasar perlu diperkenalkan bagi memenuhi keperluan untuk membangunkan negara. Proses 
pengenalan dan perlaksanaan DPT bermula seperti dalam jadual 1, apabila Mahathir Mohamad memberi arahan untuk melaksanakan dasar yang boleh membantu dalam membangunkan negara dan memilih pengenalan DPT untuk mengubah budaya dan etika kerja masyarakat Malaysia seperti budaya dan etika kerja masyarakat Jepun (peringkat memformulasikan dasar). Keputusan yang diambil untuk melaksanakan dasar ini hanya dibuat oleh Perdana Menteri (pembuatan keputusan) dan perlaksanaannya adalah secara menyeluruh dalam sektor awam dan swasta (perlaksanaan dasar). Oleh itu, penilaian terhadap perlaksanaan dasar perlu dijalankan bagi menguji tahap kejayaan perlaksanaan dasar melalui pengukuran pencapaian objektif dasar dan tahap perubahan struktur dan budaya yang berlaku setelah dasar ini dilaksanakan.

\section{Jadual 1: Teori Kitaran Dasar dalam perlaksanaan DPT}

\begin{tabular}{ll}
\hline Elemen Teori Kitaran Dasar & Dasar Pandang ke Timur (DPT) \\
\hline Pemilihan Agenda (Agenda setting) & Top-down \\
Memformulasi Dasar (Policy formulation) & Budaya dan Etika Jepun \\
Pembuatan Keputusan (Decision making) & Executive power and order \\
Perlaksanaan Dasar (Policy implementation) & Awam dan swasta \\
Penilaian Dasar (Policy Evaluation) & - Objektif dasar \\
& - Perubahan individu dan struktur \\
\hline
\end{tabular}

Dasar Pandang ke Timur yang dilaksanakan di Malaysia mempunyai matlamat yang jelas untuk melahirkan masyarakat Malaysia (tenaga kerja) yang menyumbang kepada pembangunan ekonomi negara sekali gus membentuk setiap tenaga kerja yang mempunyai jati diri dan budaya kerja yang baik seperti yang diamalkan oleh masyarakat Jepun. Masyarakat dunia mengakui, salah satu faktor kejayaan Jepun dalam membangunkan negara terutamanya dalam sektor ekonomi seterusnya diangkat sebagai salah satu negara maju di dunia adalah kerana Jepun mempunyai tenaga kerja yang terdiri daripada rakyatnya yang berdaya saing dan berdisiplin di dalam setiap pekerjaan yang mereka lakukan. Nilai yang tinggi dalam budaya kerja yang ditunjukkan mereka perlu dicontohi oleh negara lain bagi meraih kejayaan dan kemajuan seperti Jepun. Oleh yang demikian, perlaksanaan Dasar Pandang ke Timur yang dilaksanakan oleh kerajaan Malaysia wajar dibuat penilaian kerana ia dapat melihat sejauh mana perlaksanaan sesuatu dasar itu berjaya mencapai objektif dan matlamat sesuatu dasar itu dilaksanakan. Dasar Pandang ke Timur yang dilaksanakan di dalam kedua-dua sektor iaitu awam dan swasta wajar diberi perhatian untuk menilai hasil perlaksanaan DPT. Selain itu juga, penilaian yang dibuat ke atas DPT adalah signifikan kerana hasilnya boleh menyumbang kepada proses pembuatan keputusan sama ada dasar ini wajar diteruskan ataupun perlu ditamatkan perlaksanaannya.

Penilaian ke atas Dasar Pandang ke Timur yang telah dilaksanakan hampir empat puluh tahun perlu dilihat secara terperinci dari hasil yang telah dicapai baik dari segi modal insan mahupun kemajuan negara. Implementasi Dasar Pandang Ke Timur yang ingin melahirkan modal insan yang mempunyai budaya dan etika kerja yang baik boleh dinilai melalui sikap dan budaya yang ditonjolkan oleh tenaga kerja Malaysia. Setelah hampir empat puluh tahun dasar ini diterapkan dalam kalangan rakyat Malaysia, pastinya kita mampu melihat dan menilai sejauh mana dasar ini mampu diserap dan dipraktikkan oleh masyarakat Malaysia dalam mereka melakukan kerja yang diberikan oleh majikan, khususnya. Seterusnya, perlaksanaan DPT wajar dinilai adalah kerana setiap perlaksanaan sesuatu dasar oleh kerajaan pasti melibatkan kos sama ada kos berbentuk kewangan mahupun bukan kewangan. Apabila perlaksanaan sesuatu dasar itu melibatkan penggunaan kos, maka ia akan berkait rapat dengan tahap kecekapan kos. Kos berbentuk kewangan sudah tentu melibatkan proses pengeluaran peruntukan bajet bagi memastikan sesuatu dasar itu berjaya dilaksanakan. Contohnya, pelaburan bagi pihak kerajaan untuk membeli alat perakam waktu yang digunakan sebagai mesin 'punch card' di pejabat-pejabat agensi kerajaan. Kos bukan kewangan pula melibatkan kos tenaga dan masa sama ada ia relevan dilaksanakan di jabatan-jabatan kerajaan khususnya atau di sektor swasta, amnya. Jadi, perlaksanaan ini harus diambil kira untuk dinilai bagi melihat tahap kecekapan kos sesuatu dasar itu setelah ia dilaksanakan.

Contoh lain di dalam Dasar Pandang ke Timur adalah melihat aspek pendidikan yang menjadi teras kepada program pendidikan seperti program penghantaran pelajar ke negara Jepun untuk menimba 
seberapa banyak ilmu di sana di samping mengambil atau mencedok pengalaman supaya ia boleh diaplikasikan di negara ini apabila pulang ke tanah air. Program sebegini sudah tentu menelan belanja yang besar apabila kerajaan perlu menawarkan biasiswa di samping menanggung semua kos yang diperlukan ketika berada di Jepun. Kos yang ditanggung kerajaan bukan sedikit, maka ia wajar dinilai bagi melihat keberkesanan perlaksanaan dasar sekali gus dapat mengenal pasti tahap keberjayaan DPT mencapai objektifnya ataupun tidak. Setelah hampir empat puluh tahun perlaksanaannya, DPT perlu dibuat penilaian. Penilaian ke atas perlaksanaan sesuatu dasar adalah penting untuk menilai hasil keseluruhan perlaksanaan DPT. Oleh yang demikian, penilaian terhadap DPT adalah relevan dilakukan kerana penilaian terhadap perlaksanaan dasar ini boleh melihat hasil yang diperoleh kerajaan setelah ia dilaksanakan. Perlaksanaan dasar adalah selaras dengan tujuan dan keperluan kepada negara. Kerajaan akan memutuskan perlaksanaan sesuatu dasar jika sekiranya, pihak kerajaan mendapati sesuatu dasar itu relevan dilaksanakan di dalam sesebuah negara. Oleh itu, dasar ini mempunyai objektif dan matlamat tersendiri ketika ia dihasilkan dan dilaksanakan. Setelah perlaksanaan dasar dibuat, maka penilaian perlu dilakukan bagi mengenal pasti dan menilai keberkesanan sesuatu dasar tersebut terhadap pencapaian objektif dan matlamat perlaksanaannya. Penilaian juga bertujuan untuk melihat sejauh mana dasar yang dilaksanakan telah mencapai objektif dan matlamat dasar.

Selain itu, penilaian ke atas DPT relevan kerana penilaian ini mampu memberi jawapan sama ada perlaksanaan ini wajar diteruskan atau ditamatkan. Kelangsungan dasar ini boleh ditentukan berdasarkan kepada hasil penilaian yang dibuat. Sekiranya penilaian yang dilakukan memberi hasil bahawa dasar yang telah dilaksanakan ini telah mencapai objektif dan matlamat dasar, maka pihak kerajaan boleh memutuskan untuk meneruskan perlaksanaan dasar ini pada masa akan datang. Di samping itu, dasar ini boleh dilihat kerelevanannya dilaksanakan di dalam negara ini biarpun perlaksanaannya telah mencapai empat puluh tahun. Sebaliknya, jika keputusan atau hasil penilaian yang dibuat telah mendapati ia hanya mendatangkan kerugian serta gagal mencapai sebarang matlamat dan objektif yang ditetapkan, maka ia wajar ditamatkan. Sekiranya pihak kerajaan masih mahu meneruskan perlaksanaan dasar ini, maka pihak kerajaan perlu memikirkan inisiatif bagi memperkasakan dan memperkukuhkan perlaksanaan dasar mengikut keperluan semasa. Penilaian dasar juga boleh memperbaiki kelemahan terhadap perlaksanaan dasar yang sedia ada ini. Setiap dasar kerajaan, sudah pasti mempunyai kelemahan dan kekurangan dari segi perlaksanaan dan hasil yang didapati selepas perlaksanaannya. Oleh itu, penilaian yang dibuat dapat mengenal pasti kelemahan dan kekurangan yang ada sepanjang perlaksanaan dasar dan sudah pasti, ianya berupaya membantu dalam memberi pandangan dari sudut penambahbaikan dan memberi cadangan yang lebih telus berdasarkan hasil penilaian terhadap dasar yang telah dilaksanakan.

\section{Metod Kajian}

Artikel ini menggunakan kaedah kualitatif dengan menjalankan temu bual intensif dan kumpulan fokus ke atas tiga belas orang responden yang terlibat secara langsung dalam perlaksanaan Dasar Pandang ke Timur. Pandangan dan pengalaman responden diambil kira bagi menilai dan mengenal pasti proses perlaksanaan DPT yang telah dilaksanakan lebih hampir empat puluh tahun. Kajian ini turut menggunakan data sekunder dengan menilai dan meneliti maklumat diperoleh daripada buku, jurnal, tesis, artikel, laporan akhbar dan laman web yang berkaitan.

\section{Hasil Kajian}

\section{Kritikan Terhadap Teori Kitaran Dasar}

Teori Kitaran Dasar yang diperkenalkan oleh Howlett dan Ramesh (1995) telah menggariskan lima peringkat Kitaran Dasar yang perlu dilalui di dalam proses perlaksanaan sesuatu dasar iaitu pemilihan agenda (agenda setting), memformulasi dasar (policy formulation), pembuatan keputusan (decision making), perlaksanaan dasar (policy implementation) dan penilaian dasar (policy evaluation). Namun begitu, berbeza dengan perlaksanaan DPT yang diperkenalkan oleh Tun Mahathir Mohamad, 
perlaksanaannya adalah bersifat 'top-down' dan 'vertical order' serta ia tidak melalui peringkatperingkat yang sepatutnya dilalui dalam proses pengenalan dan perlaksanaan sesuatu dasar.

DPT merupakan ilham dan arahan Tun Mahathir Mohamad pada ketika itu kepada perbendaharaan dan kementerian untuk melaksanakan DPT kepada semua peringkat atau agensi iaitu awam dan swasta. DPT tidak pernah dibincangkan dan diperdebatkan di dalam Parlimen (Mohd Ikbal, 2015). Oleh itu, dasar yang diperkenalkan ini bukan merupakan dasar yang menjadi hasrat rakyat tetapi ia adalah kemahuan pemimpin apabila Tun Mahathir Mohamad merasakan dasar ini perlu diperkenalkan bagi mengubah tingkah laku dan budaya rakyat Malaysia dalam bekerja, khususnya. Pengaplikasian teori kitaran dasar sebagai asas dan panduan di dalam membuat penilaian DPT adalah rasional untuk menilai perlaksanaan DPT dalam tempoh hampir empat dekad. Teori dasar mengandaikan penilaian sesuatu dasar kepada faktor-faktor dalaman menjadi ukuran kepada keberjayaan sesuatu dasar. Faktor dalaman yang menjadi ukuran terhadap penilaian dasar adalah seperti pencapaian matlamat dan objektif dasar, kecekapan perbelanjaan dan kos, impak dan hasil dasar, tempoh masa serta strategi perlaksanaan.

\section{Rajah 2: Model Teori Kitaran Dasar dalam Penilaian DPT}

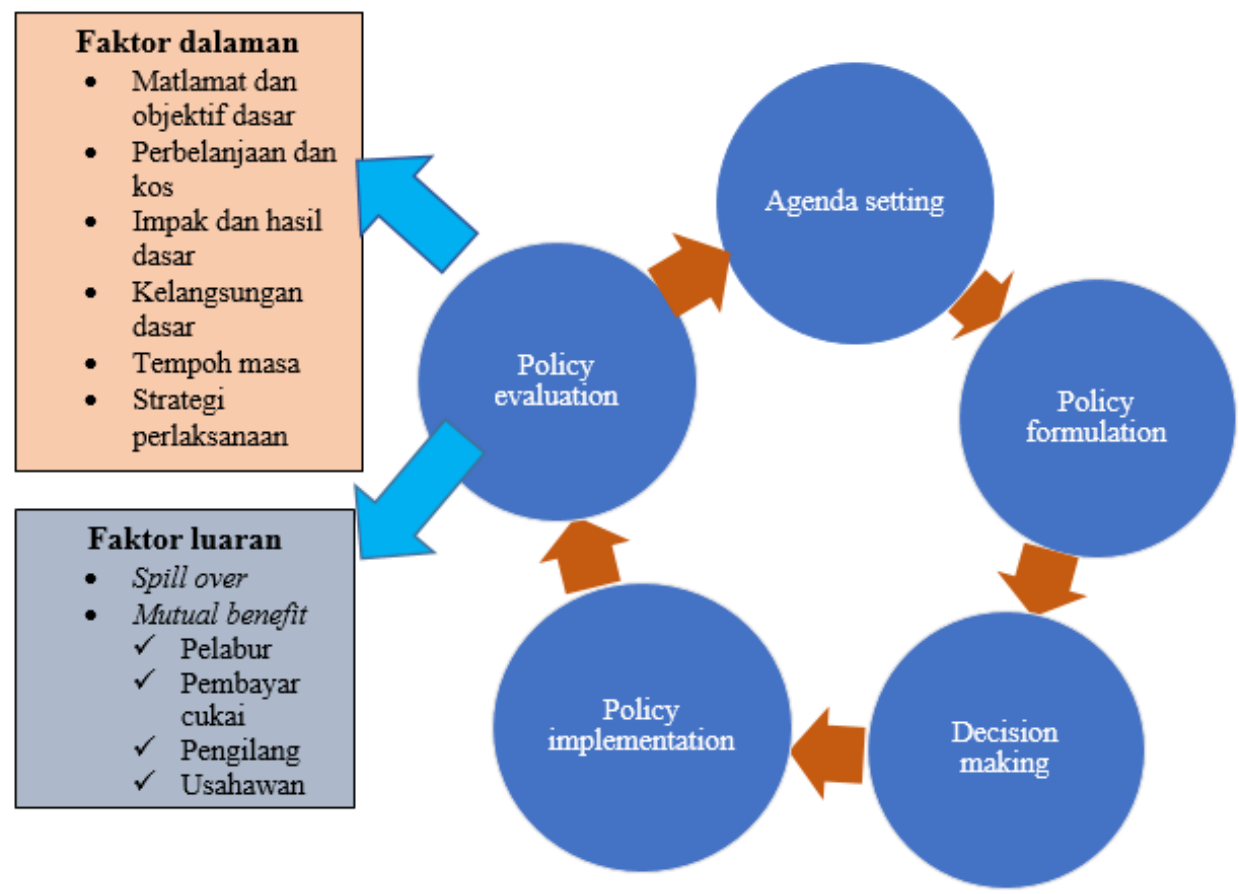

Peringkat penilaian ini, hanya mengukur pencapaian dasar berasaskan faktor dalaman yang mana ia merupakan pengukuran dan penilaian terhadap pencapaian yang dinikmati oleh Malaysia. Walau bagaimanapun, penilaian terhadap dasar menggunakan teori ini mempunyai satu kelemahan apabila peringkat ini tidak menguji dan mengukur faktor-faktor luaran. DPT merupakan dasar luar yang melibatkan dana dan kebergantungan dengan Jepun. Pelabur, pembayar cukai, pengilang dan usahawan daripada Jepun antara pihak yang terlibat di dalam menjayakan perlaksanaan DPT. Malaysia adalah negara yang unik apabila menggunakan model pembangunan mengikut negara luar dan disesuaikan dengan negara sendiri. Bilamana kita membina dasar daripada budaya luar, faktor-faktor luaran perlu dinilai bagi melihat sejauh mana dasar ini memberi manfaat kepada kedua-dua pihak (mutual benefit).

Faktor luaran seperti 'spill over' dan 'mutual benefit' tidak diukur dan dinilai di dalam peringkat penilaian dasar. DPT melibatkan hubungan dan kerjasama di antara dua negara iaitu Malaysia dan Jepun. Peringkat penilaian dasar ini tidak melihat dan mengukur hasil perlaksanaan dasar sama ada ia hanya memberi manfaat kepada satu pihak sahaja (spill over) atau mungkin ia memberi manfaat kepada kedua-dua pihak (mutual benefit). Oleh itu, artikel ini berjaya mengutarakan kelemahan di dalam teori penilaian dasar apabila penilaian yang dibuat hanya ke atas faktor dalaman semata-mata 
tanpa melihat faktor luaran yang mana dasar yang diperkenalkan ini tidak hanya melibatkan satu pihak sahaja tetapi perlaksanaan dasar ini melibatkan dua negara iaitu Malaysia dan Jepun.

\title{
Kejayaan DPT Dalam Mengubah Budaya dan Etika Kerja Masyarakat Malaysia
}

Walaupun perubahan sikap tidak berlaku secara menyeluruh, tetapi ia masih wujud perubahan yang baik meskipun tidak semua berubah menjadi seperti pekerja di negara Jepun. Masih ada bekas pelajar yang telah berjaya meniru budaya Jepun dalam melaksanakan tugas yang diberi seperti rajin bekerja dan malu apabila mereka tidak berjaya mencapai matlamat seperti yang diharapkan oleh sesebuah organisasi. Ini adalah sama seperti yang telah diakui oleh Tun Mahathir Mohamad ketika ditemu bual oleh penulis:

\begin{abstract}
"Pelajar yang dihantar ke negeri Jepun, mereka nampak ada menerap sedikit sebanyak etika kerja orang Jepun walaupun masih adalah yang tak berubah, tapi ada yang berubah, ada yang berubah boleh kata fully, mereka mempunyai work ethics yang ala Jepun, rajin bekerja dan menumpu kepada kualiti. Dan dia merasa malu kalau dia tidak capai matlamat. But I think there is a very small minority. Dia absorbed. Tapi majoriti adalah sedikit sebanyak adalah yang bertukar. They absorbed. Sebenarnya mereka yang kita hantar ke Jepun, balik tak timbul masalah, sebaliknya mereka yang kita hantar ke Eropah lebih dahsyat lagi ke Amerika, bila balik mereka berubah. Mereka absorbed cara hidup sana, nilai hidup sana, mereka buat demand itu demand ini. Macam-macam, tapi yang balik dari Jepun, mereka berkerja dan dia lebih berjaya".
\end{abstract}

Tun Mahathir Mohamad mengakui, pelajar yang dihantar ke Jepun kebanyakannya bekerja dan lebih berjaya berbanding pelajar Malaysia yang ditaja melanjutkan pengajian di negara-negara Eropah seperti UK dan US. Pelajar di Eropah lebih mudah terpengaruh dengan budaya Barat yang dilihat tidak sesuai dengan budaya kita sebagai masyarakat Timur yang kaya dengan nilai-nilai murni dalam kehidupan seharian. Perubahan sikap oleh pelajar yang mendapat pendidikan secara formal dari negara Jepun dapat dilihat apabila mereka pulang dan bekerja di Malaysia. Mereka bekerja dengan penuh dedikasi dan mengamalkan budaya kerja orang Jepun dalam pekerjaan mereka. Bahkan, mereka turut mengamalkan gaya dan nilai hidup orang Jepun dalam kehidupan seharian mereka.

Antaranya ialah mereka menjadi seorang individu yang komited dan bersungguh-sungguh dalam melakukan tugas yang diberi, berdisiplin, menepati masa, malu sekiranya tidak mencapai sasaran organisasi dan mementingkan kualiti dalam hasil kerja ataupun produktiviti. Dalam kehidupan seharian juga, mereka menjadi seorang individu yang bertanggungjawab dalam menjaga kebersihan dan terdapat informan yang ditemu bual berjaya mengamalkan gaya hidup orang Jepun dalam kehidupan mereka. Selain itu, pekerja yang bekerja di syarikat Jepun yang beroperasi di Malaysia juga mengamalkan budaya dan etika kerja Jepun yang diterapkan oleh syarikat berkenaan. Syarikat Jepun yang beroperasi di Malaysia mengamalkan budaya kerja Jepun. Oleh itu, pekerja-pekerja berkenaan tiada pilihan dan perlu mematuhi segala peraturan dan amalan yang menjadi budaya kerja Jepun seperti punctuality, berdisiplin, mengutamakan kebersihan, mementingkan kualiti dan produktiviti, bekerjasama serta setia dan patuh dengan majikan.

Bekerja di syarikat Jepun juga terikat dengan waktu kerja yang telah ditetapkan dan semua pekerja perlu mematuhi setiap waktu kerja yang telah ditentukan dan mereka menggunakan sistem punch card supaya semua pekerja mematuhi waktu kerja yang telah diberi. Amalan menjaga kebersihan juga menjadi amalan setiap pekerja dan majikan sehingga majikan akan mengutip sendiri sampah yang mereka temui dan ini merupakan contoh terbaik yang ditunjukkan oleh majikan kepada pekerja. Pekerja akan berasa malu kepada majikan sekiranya mereka tidak menjaga kebersihan di sekitar ruang tempat bekerja mereka. Hal ini akan menyebabkan pekerja sentiasa memastikan tempat kerja mereka sentiasa bersih dan kemas. Amalan 5S yang diterapkan di setiap organisasi di Malaysia juga menghasilkan individu pekerja yang cermat dan sentiasa mengutamakan kebersihan. 
Amalan dan budaya kerja yang diamalkan oleh setiap pekerja tidak hanya diamalkan di tempat kerja sahaja malah ia menjadi amalan dan rutin harian setiap daripada mereka. Mereka tidak hanya mengamalkan disiplin dan menjaga kebersihan hanya di tempat kerja malah amalan ini terus diamalkan di rumah mahupun di luar rumah. Amalan positif ini telah menjadi sebahagian daripada kehidupan individu yang secara tidak langsung mengamalkan etika dan budaya kerja Jepun. Budaya kerja Jepun ini bukan hanya menjadi amalan orang Jepun di tempat kerja malah ia merupakan amalan peribadi seseorang sehingga ia diamalkan tidak hanya ketika mereka berada dalam sektor pekerjaan sematamata. Oleh yang demikian, amalan budaya kerja ini mampu memberi perubahan sikap dengan mengamalkan budaya murni ini di samping berubah menjadi individu yang lebih baik dalam kehidupan seharian.

\section{Kesimpulan}

Keseluruhan artikel ini mengetengahkan mengenai teori kitaran dasar yang digunakan untuk membuat penilaian dan analisis berkaitan dengan perlaksanaan DPT yang telah menghampiri empat puluh tahun perlaksanaannya. Penilaian ke atas dasar yang dilaksanakan oleh pihak kerajaan berupaya menemukan hasil dan impak perlaksanaan dasar. Penilaian juga membantu pihak kerajaan untuk membuat keputusan sama ada dasar yang telah dilaksanakan tersebut akan diteruskan atau dihentikan selain pihak kerajaan boleh merencana penambahbaikan jika hasil penilaian telah menunjukkan penambahbaikan perlaksanaan dasar perlu dilakukan. Penilaian ke atas Dasar Pandang ke Timur yang telah dilaksanakan adalah untuk menentukan tahap keberkesanannya mencapai matlamat dan objektif dasar. Oleh itu, penilaian secara menyeluruh harus dilaksanakan untuk menilai operasi dan hasil program seperti yang terdapat dalam disiplin ilmu penilaian dasar awam. Perbincangan mengenai keseluruhan penilaian dasar dalam artikel ini turut berupaya memberi pendedahan kepada penganalisis dasar untuk dijadikan panduan di dalam membuat penilaian terhadap dasar awam yang dilaksanakan oleh pihak kerajaan.

\section{Rujukan}

Ahmad Atory. (2002). Politik dan Dasar Awam di Malaysia. Cheras, Kuala Lumpur: Utusan Publications \& Distributors Sdn Bhd.

Ahmad Sohaimi. (2011). Dua Dekad Dasar Pandang ke Timur Satu Penilaian Aspek Pendidikan 1982-2002. Tanjung Malim, Perak: Penerbit Universiti Pendidikan Sultan Idris.

Ahmad Sohaimi. (2013). Hubungan Malaysia Jepun: Diplomasi dan Pendidikan. Kuala Lumpur: Penerbit Universiti Malaya.

Anderson, J. E., Brady, D. W., Bullock, C. S. \& Stewart, J. (1984). Public Policy and Politic in America. Second Edition. California: Brooks/Cole Publishing Company.

Birkland, T. A. (2005). An Introduction to the Policy Process: Theories, Concepts, and Models of Public Policy Making. United States, America: American National Standard for Sciences.

Bosso, J. C. (1987). Presticides \& Politics: The Life Cycles of a Public Policy. University of Pittsburgh Press.

Dasar Pandang Ke Timur. Laman web Kementerian Penerangan Malaysia. http://pmr.penerangan.gov.my/indx.php/maklumat-kenegaraan/240 dasar pandang ke Timur.html [15 Mac 2014].

Dorey, P. (2005). Policy Making in Britain: An Introduction. New Delhi: SAGE Publication. Dunn, W, N. (2003). Public Policy Analysis: An Introduction. New Jersey: Pearson Prentice Hall.

Furuoka, F. (2007). Malaysia-Japan Relations under the Mahathir: Case studies of The Look East Policy and Japanese Investment in Malaysia. University of California Press.

Goggin, M. L. et. al. (1990). Implementation Theory and Practice. London: Scott.

Hanim Ismail. (2020). Dasar Pandang ke Timur: Perubahan Struktur dan Budaya (1982-2019). Tesis Dr. Falsafah. Universiti Kebangsaan Malaysia.

Howlett, M \& Ramesh, M. (1995). Studying Public Policy: Policy Cycles and Policy Subsystems. Oxford University Press. 
Howlett, M. (2011). Designing Public Policy: Principles and Instruments. London: Routledge Taylor \& Francis Group.

Jakob Edler. et. al. (2012). The Practice of Evaluation in Innovation Policy in Europe. Research Evaluation 21, hlm. 167-182.

Kartini Aboo Talib (pnyt). (2017). Dasar Pandang ke Timur: Pencapaian, Adaptasi, dan Cabaran. Bangi: Penerbit Universiti Kebangsaan Malaysia.

Kartini Aboo Talib, Nidzam Sulaiman \& Suhana Saad. (2017). Assessing the Look East Policy: Moving Beyond Work Culture and Ethics Asian Social Science 9(17).

Kartini Aboo Talib. (2012). Policy Implementation by The New Street Level Bureacrats in Non Profit Organizations: Overcoming the Dilemma. Pertanika, J. Soc. Sci. \& Hum 20 (2): 333-352..

Kraft, M. E. \& Furlong, S. R. (2004). Public Policy: Politics, Analysis and Alternatives. Washington: A Division of Congressional Quarterly, Inc.

Lindblom, C. E. \& Woodhouse E. J. (1993). The Policy- Making Process. United States,America: Library of Congrese Cataloging in Publication Data. London. Routledge Taylor \& Francis Group

Loury, G. C. (pnyt) et. al. (2005). Ethnicity, Social Mobility and Public Policy: Comparing The US and UK. Cambridge University Press.

MacRae, D. \& Wilde, J. A. (1979). Policy Analysis for Public Decisions. California: University of North Carolina.

Malike Ibrahim. (2008). Dasar Awam di Malaysia; Suatu Pengenalan. Petaling Jaya: IBS Buku Sdn. Bhd.

Massimo Motta. (2009). Compettition Policy: Thoery and Process. London: Cambridge

Mohd Afendi \& Junaidi. (2017). Meninjau Kembali Dasar Pandang ke Timur Mahathir: Penelitian Aspek Perlaksanaan dan Implikasi. Malaysian Journal of Society and Space 12(9): 79-91.

Mohd Ikbal Mohd Huda. (2015). Bantuan Pembangunan Rasmi Jepun ke Malaysia 1966 -2010: Impak Ke Atas Pembangunan Sosioekonomi Malaysia. Tesis Dr. Falsafah. Fakulti Sastera dan Sains Sosial, Universiti Malaysa: Kuala Lumpur.

Portal Maklumat Rakyat: Jabatan Penerangan Malaysia. Dasar Pandang Ke Timur. http://pmr.penerangan.gov.my/indx.php/maklumatkenegaraan/240dasarpandangkeTimur $\mathrm{html}$ [15 Mac 2012].

Sabatier, P. A. (pnyt). (1999). Theories of the Policy Process. United State: West View Press.

Sabitha Marican. (2001). Dasar Awam di Malaysia; Isu dan Konsep. Cheras, Kuala Lumpur: Utusan Publications \& Distributors Sdn. Bhd.

Shafritz, J. M. \& Russell, E. W. (2013). Introducing Public Administration, $9^{\text {th }}$ Edition. New York: Routledge.

Suseela Devi. (2014). Malaysia and India's Look East Policy: Hand in Hand Towards Greater Cooperation. Journal of Administrative Science 11(1).

Uqbah Iqbal. (2017). Sejarah Pemikiran Pandang Ke Timur. Kepentingan Jepun dalam Pembangunan Sosioekonomi Malaysia (1960-1980). Penerbit Universiti Kebangsaan Malaysia.

Weimer, D. L. \& Vining, A. R. (2005). Policy Analysis: Concepts and Practice.New Jersey: Pearson Prantice Hill.

Weiss, C, M. (1998). Evaluation. New Jersey: Prentice Hall, Upper Saddle River.

Whitske Overtoom. (2014). Mahathir's Look East Policy: Changing the Values of the Malays. Economic Development and Social Change in Southeast Asia.

Yusof Ismail (pnyt). (2010). Dasar-dasar Utama Kerajaan Malaysia. Kuala Lumpur: $\quad$ Percetakan Zafar Sdn. Bhd. 